\title{
Business or basic needs? \\ The impact of loan purpose on social crowdfunding platforms
}

\author{
Hadar Gafni, Marek Hudon, Anaïs Périlleux
}

Crowdfunding has created new opportunities for poor microentrepreneurs. One crucial question is the impact that the purpose of a loan-either business investment or basic necessities-may have on the success of a campaign. Investigating a prosocial crowdfunding platform, we find that loans taken out to meet basic needs are funded faster than business-related loans, especially for small amounts, which can be explained by the prosocial motivation of microlenders. Moreover, female microborrowers are funded faster than men, especially for basic needs loans. Our results therefore suggest an ethical blind spot, since prosocially motivated crowdlenders may unintentionally end up producing adverse effects, replicating gender role by supporting women to a lesser extent when they apply for business loans. This finding expands prosocial motivational theory in ethical finance.

Keywords crowdfunding, business loans, basic necessities, ethical finance, microfinance, microlending, gender preference.

JEL Classifications F35, G21, G28, L31, M14

\section{CEB Working Paper N²0-008 Mai 2020}

Université Libre de Bruxelles - Solvay Brussels School of Economics and Management Centre Emile Bernheim 


\title{
Business or basic needs? The impact of loan purpose on social crowdfunding platforms
}

\author{
Hadar Gafni* \\ Department of Strategy and Innovation, Copenhagen Business School, Denmark \\ hg.si@cbs.dk \\ Marek Hudon \\ Université Libre de Bruxelles (U.L.B.), CEB \& CERMi, Brussels, Belgium
}

Anaïs Périlleux

Université Catholique de Louvain (UCLouvain), CIRTES, IRES, \& CERMi, Louvain-la-Neuve, Belgium

*Corresponding author

Hadar Gafni, Marek Hudon and Anaïs Périlleux have contributed equally to this work

This is the pre-print version of

Gafni, H., Hudon, M., Périlleux, A. (Forthcoming), "Business or basic needs? The impact of loan purpose on social crowdfunding platforms”, Journal of Business Ethics.

\section{Acknowledgements:}

We thank Zineb Aouni, Judith Behrens, Oscar Bernal, Marc Labie, Marthe Nyssens, Patrick Reichert, Ariane Szafarz and Vera Rocha for their very useful comments. Hadar Gafni has started this research during a research stay at CERMi, Université Libre de Bruxelles (ULB). Anaïs Périlleux carried out this research in the framework of an Action de Recherche Concertée programme (ARC) entitled Platforms Operations and Regulation in the Sharing Economy (PROSEco). 


\title{
Business or basic needs? The impact of loan purpose on social crowdfunding platforms
}

\begin{abstract}
Crowdfunding has created new opportunities for poor microentrepreneurs. One crucial question is the impact that the purpose of a loan-either business investment or basic necessities - may have on the success of a campaign. Investigating a prosocial crowdfunding platform, we find that loans taken out to meet basic needs are funded faster than business-related loans, especially for small amounts, which can be explained by the prosocial motivation of microlenders. Moreover, female microborrowers are funded faster than men, especially for basic needs loans. Our results therefore suggest an ethical blind spot, since prosocially motivated crowdlenders may unintentionally end up producing adverse effects, replicating gender role by supporting women to a lesser extent when they apply for business loans. This finding expands prosocial motivational theory in ethical finance.
\end{abstract}

Keywords: crowdfunding, business loans, basic necessities, ethical finance, microfinance, microlending, gender preference. 
Business or basic needs?

\section{Introduction}

Microentrepreneurs contribute significantly to economic activities and growth in developing countries (Khavul et al., 2009; Berns et al., 2020). A crucial issue for these entrepreneurs is access to finance (Bruton et al., 2015). Being excluded from traditional sources of funding, they typically borrow from relatives but also rely on local moneylenders, who can charge usury rates because of their monopoly situation (Collins et al., 2009). During the 1980s, microlending organizations developed to respond to this market failure and empower microentrepreneurs in developing countries (Battilana \& Dorado, 2010; Dorfleitner et al., 2019). Nevertheless, many poor microentrepreneurs still lack access to finance (Demirguc-Kunt et al., 2018). As a result, lending-based prosocial crowdfunding has grown rapidly, offering the financially marginalized a new opportunity to obtain funding (Fleming \& Sorenson, 2016; Lehner \& Harrer, 2019a). Prosocial crowdfunding has an inherent ethical dimension, since funders do not only pursue financial outcomes but, rather, social impact. It may thus be considered to be part of a more global phenomenon of ethical, collective, and sustainable entrepreneurship. Prosocial crowdfunding platforms, with their clear ethical agenda of social or environmental value as an ultimate objective, belong to the ethical finance movement (Scarlata, \& Alemany, 2010; Cumming et al., 2016; Montgomery et al., 2012; Aldohni, 2018).

There is a relative paucity of literature discussing the factors or mechanisms that make microborrowers' loan applications attractive on prosocial lending-based crowdfunding platforms (Galak et al., 2011; Allison et al., 2015; André et al., 2017; Berns et al., 2020). Early research conceptualized the crowdfunding phenomenon (Hildebrand et al., 2017; 


\section{Business or basic needs?}

Afuah \& Tucci, 2012), its geographical spread (Agrawal et al., 2011; Guenther et al., 2018), and related business and intermediation models (Ashta et al., 2015); it also suggested various crowdfunding models (Belleflamme et al., 2014; Kappel, 2009).

Current literature focuses on the narratives in loan applications made by microborrowers to crowdlenders (Allison et al., 2013; Allison et al., 2015; Moss et al., 2015) and the underlying ethical motivations (Berns et al., 2020) or the social proximity between the two groups (Galak et al., 2011). Nevertheless, we know little about the importance that lenders place on the purpose of the loan, even though this is a key element in each application. In their closing remark, McKenny et al. (2017, p. 295) argued that "future research could examine how the goal set by the entrepreneur and the current progress toward meeting that goal influences crowdfunding investor behavior". We will respond to their call by analyzing the impact of the purpose of a loan on the success chances of a crowdfunding campaign.

Three main options are available to microborrowers to qualify the type of loan they apply for on crowdfunding platforms. First, they can select business loans related to an income-generating activity, thus showing entrepreneurial drive and a desire to grow the business. Second, they can state that the purpose of the loan is to pay for expenses related to basic needs, such as health care, child education and house repayments. Loans for basic necessities are not related to business or income-generating activities and are thus potentially riskier for lenders (Armendariz \& Labie, 2011). Third, loans might be requested for consumption, i.e. personal purchases such as a private car, or other purposes that are neither directly income-generating, nor related to basic needs. To the best of our knowledge, the impact of loan purpose on the success chances of a campaign 


\section{Business or basic needs?}

has not yet been investigated, despite being a crucial characteristic of the value proposition made to the crowdlender.

Relying on motivational theory, we analyzed the way in which a loan's purpose might impact the success chances of a fundraising campaign among prosocially motivated crowdlenders. To do so, we used an original database of more than 767,000 loans channeled through Kiva, the largest prosocial lending-based crowdfunding platform. This dataset is unique since it includes a classification of all loans by purpose. Business loans being generally larger and male-oriented, we also investigated whether there might be a loan size and gender moderating effect, respectively. Finally, we performed additional checks using matching methods to test the robustness of our results.

Our findings are threefold. First, the empirical analysis revealed that loans intended for basic necessities were funded faster than those for business investment or for other consumption. These results can be explained by the prosocial or ethical motivation of crowdlenders. Second, results indicate a loan size moderating effect. One potential explanation for this is crowdlenders' reluctance to support large non-income-generating loans, which could lead to over-indebtedness; for contrary to business loans, these loans do not generate the income needed for repayment (Schicks, 2014; Hudon et al., 2020). Third, we found a gender moderating effect. More precisely, there was a preference for female borrowers, but this effect was weaker when the purpose of the loan was a business activity. Female microborrowers are funded faster than men, especially when applying for basic needs loans. This could produce adverse effects, supporting gender role bias and driving women away from business activities. 


\section{Business or basic needs?}

Our research makes three contributions to the business ethics literature. First, it expands our understanding of decision making by prosocially-motivated lenders in a context of high information asymmetry: crowdlending to microborrowers. Crowdlenders generally live far away from the microborrowers they might support; moreover, they have neither the practical opportunity nor the time to collect information by themselves, which makes the lending decision more challenging. Second, it highlights how important the purpose of the loan is in prosocial (micro)financing. In particular, our research contributes to the emerging literature on how, thanks to the Internet, the involvement of the crowd can alter funding allocation and the type of project supported within an industry (Burtch et al. 2015; Mollick \& Nanda 2015). Third, looking deeper at gender interactions and their influence on the chances of financing success, our research confirms a gender effect, and contributes to the literature on gender and business ethics. In particular, this gender interaction effect suggests an ethical blind spot, since the choices of prosocially motivated microlenders may unintentionally end up having adverse consequences, driving women away from business and, thus, partly going against prosocial ethical values (Sezer et al., 2015).

Surprisingly, our results suggest that the combination of multiple prosocial motives could lead to a partially counter-productive effect from a prosocial perspective and eventually produce an ethical blind spot. There might be a trade-off between prosocial motives so that they may not always reinforce each other. We therefore need to warn prosocially motivated actors against ethical blind spots. These findings also have managerial implications for ethical finance industries.

The rest of the paper is organized as follows. The next section sketches out the theoretical background and formulates research hypotheses related to the impact of loan 
Business or basic needs?

purpose and the gender moderating effect. In Section 3, we describe our database, present the prosocial crowdfunding platform we worked with, and outline the test methodology. Section 4 describes the results of the parametric hazard model and presents some robustness checks. Section 5 discusses the results and describes their policy implications. Section 6 concludes the article.

\section{Theory and Hypotheses}

\section{Crowdfunding and microentrepreneurship}

Raising enough capital to start or develop a company is crucial for all entrepreneurs (Figueroa-Armijos \& Johnson, 2016). While access to funding is a challenge for all, it is particularly problematic for poor microentrepreneurs, who tend to be excluded from the traditional financial sector (Bruton et al., 2015). Microfinance organizations tackle financial exclusion by servicing these microentrepreneurs. They provide various services, including microsavings accounts and microinsurance, but their best-known product is microlending or microcredit (Armendariz \& Labie, 2011).

Compared with microfinance, crowdfunding platforms are a more recent funding mechanism. These Internet platforms facilitate access to finance for entrepreneurs. Crowdfunding has become very popular in a short space of time, making it a "poster child” of the new online mechanisms of entrepreneurial finance (Mc Kenny et al., 2017, Baierl, 2019). Crowdfunding platforms create new financing opportunities, as they bypass the traditional financing system and let the crowd decide which project or applicant is worth funding (Belleflamme et al., 2015). In 2015 alone, more than 1,250 online crowdfunding platforms helped individuals and ventures around the world raise 
Business or basic needs?

\$34 billion (Massolution, 2016). Crowdfunding platforms have been providing funding to entrepreneurs or projects in places that had often been excluded by traditional funders (Allison et al., 2013).

Crowdlending, also called “crowdfunded debt”, accounts for the largest percentage of total crowdfunding volume (Fleming \& Sorenson, 2016). Among the platforms that have been set up, the likes of Kiva, Babyloan, and Zidisha enable crowdlenders to fund poor microentrepreneurs either directly or indirectly, usually in developing countries. As is the case in other sectors, these platforms can alter the types of project funded by the microfinance industry. In the context of arts and reward-based crowdfunding, Mollick \& Nanda (2015) and Younkin \& Kuppuswamy (2017), respectively, have shown that crowd involvement in funding decisions can significantly reduce discrimination and favor socially valued projects.

There are many explanations for the success (or failure) of crowdfunding campaigns. Mollick (2014) and Colombo et al. (2015) found that personal networks and internal social capital developed inside the crowdfunding community were positively related to the success of a campaign, even though the effect was mediated by the amount of capital to be raised and the number of funders involved in the early days. Buttice et al. (2017) also referred to the influence of internal social capital built up by serial entrepreneurs on crowdfunding platforms. Likewise, competition among projects affects a campaign's chances of success. Ly and Mason (2012) found that competition was negatively related to the speed of funding. This is particularly relevant in the case of charitable or pre-purchase forms of crowdfunding, where the variety of projects is greatest (Younkin \& Kashouli, 2016). 
Business or basic needs?

Regarding crowdlending to microentrepreneurs, researchers have started to analyze descriptions in entrepreneurs’ profiles but reached contradictory conclusions. Allison et al. (2015) concluded that lenders tended to prefer narratives offering the opportunity to help others, whereas narratives featuring accomplishment rhetoric achieved a slower funding speed. On the contrary, Moss et al. (2015) pointed out that microentrepreneurs who signaled autonomy, risk-taking, and competitive aggressiveness received funding more quickly than those who signaled empathy, courage, warmth, and conscientiousness. However, these studies have neglected the role played by a loan's purpose in the success of a microentrepreneur's crowdlending campaign. We propose to analyze this role by applying self-determination theory.

\section{Self-determination theory (SDT) and crowdfunding}

In order to understand funding decisions in crowdlending to microentrepreneurs, we must take into account crowdlenders’ motivations for supporting a project. Since loans on prosocial lending platforms do not bear any interest, users are not drawn to the website by purely extrinsic motivations, such as potential financial rewards, but by prosocial motivations, such as the desire to expend effort to help others (Grant, 2007). Consequently, crowdlenders analyze loan applications not only by using traditional criteria but, also, prosocial criteria influenced by psychological factors (Galak et al., 2011; Allison et al., 2015). Self-determination theory (SDT) is thus especially relevant if we wish to analyze funding decisions on prosocial crowdfunding platforms (Allison et al., 2015).

SDT distinguishes between extrinsic motivation, which occurs whenever a person undertakes an activity for its instrumental value (to obtain some external outcome), and 


\section{Business or basic needs?}

intrinsic motivation, where the outcome is direct enjoyment of the activity itself. Ryan and Deci (2000, p. 60) explained that "Although intrinsic motivation is clearly an important type of motivation, most of the activities people do are not, strictly speaking, intrinsically motivated”.

Organismic integration theory, a subfield of SDT, has theorized the different forms of extrinsic motivations. In particular, Ryan and Connell (1989) classified four forms of extrinsic motivation-along a continuum ranging from pure "external regulation” to intrinsic motivation-according to the degree to which the behavior has been internalized, or the extent to which the goal of the activity has been absorbed in the self. Indeed, we may speak of pure external extrinsic motivation when a behavior is "performed to satisfy an external demand or obtain an externally imposed reward contingency” (Ryan \& Deci, 2000, p. 61). The three other types of extrinsic motivation correspond to different modes of behavior regulation resulting from an internalization process: introjection, when a person performs an act in order to enhance or maintain self-esteem and avoid feeling guilty; identification, when they have identified with the personal importance of a behavior; and integration, when they make a self-assessment and bring new regulations into congruence with their other values and needs (Ryan \& Deci, 2000).

The more internalized, and thus self-determined, the behavior, the more efficient it is. Ryan and Deci (2000) identified three basic psychological needs, which tend to stimulate the internalization of extrinsic motivation: perceived competence, autonomy, and relatedness. First, perceived competence is related to the feeling of being efficacious in relation to the pursued goal. Second, individuals should also be 


\section{Business or basic needs?}

autonomous in the pursuit of that goal. For example, they should not be externally controlled through extrinsic (such as monetary) rewards. Finally, they should have a sense of relatedness, which is defined as "a sense of belongingness and connectedness to the persons, group, or culture disseminating the goal” (Ryan \& Deci, 2000, p. 64).

Prosocial motivation may be considered an internalized extrinsic motivation based on identified and integrated regulation (Bagozzi \& Dholakia, 2006; Grant, 2007; De Cooman et al., 2011) ${ }^{1}$. It differs from intrinsic motivation in two ways: First, motivation derives from the instrumental value of helping others, not from enjoyment of the task in itself. Second, prosocial motivation is based on other-oriented values that can be more or less internalized, contrary to the fully autonomous regulation of intrinsic motivation (Grant \& Berry, 2011). De Cooman et al. (2011) explained that prosocial motivation could be viewed as value-based regulation. Furthermore, Grant (2007, 2008) showed that prosocial motivation could be stimulated by the three basic psychological needs identified by Ryan and Deci (2000). Grant (2008, p. 50) explains that prosocial motivation will be higher when individuals "experience autonomy in acting freely to benefit others, competence in successfully helping others, and relatedness in connecting their actions to outcomes that matter in the lives of other people”.

Prosocial motivations may be at work in various circumstances. The literature has shown their importance in social entrepreneurship (Conger, McMullen, Bergman, \& York, 2018; Bauwens et al., 2019) or workers’ engagement in social enterprises (Grant

\footnotetext{
${ }^{1}$ Prosocial motivation used to be conceptualized as intrinsic motivation. With the development of SDT, recent studies have stressed that prosocial motivation actually corresponds to an internalized extrinsic motivation (Grant, 2008; De Cooman et al., 2011).
} 
Business or basic needs?

\& Berry, 2011; De Cooman et al., 2011; Brolis \& Nyssens, 2019). In ethical finance, prosocial motivations are also called upon to explain why people choose to save in ethical banks or to invest in ethical funds (Cornée \& Safarz, 2014; Barigozzi \& Tedeschi, 2019).

In the specific case of crowdlending, prosocial motivations have been evoked in two main contexts that have core ethical value in common (Bendell, 2017). First, they can explain why the crowd wishes to lend to social ventures that have a social or environmental mission as their primal goal (Lehner, 2013, 2014; Parhankangas \& Renko, 2017; Schwienbacher, 2015). In this case, the social dimension of lending comes from the positive externalities to be generated by the projects undertaken by the ventures. Second, prosocial motivations can also explain why the crowd chooses to lend to poor microentrepreneurs excluded from the banking system (Bruton et al, 2015; Allison et al., 2015). In this case, the social dimension of lending comes from the profile of the impoverished entrepreneurs.

Referring to SDT, we will investigate how the purpose of a loan-either for business or basic necessities_affects the funding decisions of prosocially motivated crowdlenders.

\section{Hypotheses development: Loan purpose}




\section{Business or basic needs?}

During the first years of institutional microlending, attention focused on financing loans for business activities ${ }^{2}$. Indeed, microlending was not originally intended for individual consumption smoothing, but to help fund investment in business and empower entrepreneurs (Bruton et al., 2015). This policy was driven by the idea that lending to small entrepreneurs to support their economic activity would be an efficient way of encouraging economic growth in developing countries, since these small businesses would generate additional income (Armendariz \& Labie, 2011).

However, this approach to microlending has recently been challenged by arguments supporting the provision of consumption loans to microentrepreneurs. Indeed, in the context of microfinance, consumption loans are generally used to finance basic and urgent needs (such as health care, education, and housing) that would be financed anyway, but through other, more expensive, informal sources of funds (Guérin et al., 2012).

Based on Self-Determination Theory, we can hypothesize that, in the context of loans to poor microentrepreneurs, crowdlenders would prefer to support requests for microloans that are intended for essential necessities rather than requests for business or consumption loans. Three main arguments support this hypothesis.

First, according to SDT, prosocial motivation derives from the instrumental value of helping others. Consequently, nonfinancial aspects tend to play a crucial role in funding decisions of crowdlenders. In that sense, prosocially motivated crowdlenders primarily

\footnotetext{
${ }^{2}$ In the existing literature, this type of funding is also referred to as a business-purpose loan (for example, in Johnston \& Morduch, 2008) or as a loan for productive purposes (Imai \& Azam, 2010, inter alia). Nevertheless, the meaning is essentially the same.
} 


\section{Business or basic needs?}

wish to respond to welfare needs. As stressed by Bendell (2017), prosocially motivated individuals aim to benefit other people, due to their concern for the welfare of others. Loans for necessities have a concrete, direct social impact since, by definition, they enable the provision of basic necessities required by entrepreneurs. They thus have a more vital dimension than business loans. Consequently, referring to SDT, funding basic necessity loans could increase microlenders' feelings of competence, one of three basic psychological needs underlying prosocial motivation.

Second, microloans intended for necessities, which are directly related to human needs, are apparently more easily internalized than business-related loans. The internalization process is key in SDT since prosocial motivation is based on values that are largely internalized (Grant \& Berry, 2011). Grant (2007) has shown that relatedness, which can be defined as the need that individuals have to connect their actions to outcomes that matter in other people's lives, is a major factor of the internalization process that increases prosocial motivation. Prosocially motivated microlenders will tend to feel closer and more empathic to situations that require urgent help, and thus be more likely to support people in such situations rather than those less in need. They identify themselves with the personal importance of helping these microborrowers due to the salience, and potentially urgent character, of the requests for necessity-based loans. For example, previous studies have shown that lenders tended to be drawn to narratives richer in language expressing blame and present concern (Allison et al., 2013).

Third, lenders active on social crowdfunding platforms tend to prefer projects that do not stimulate "external regulation” and thus do not refer to extrinsic monetary rewards, which may be perceived by lenders as controlling and will reduce the feeling of 
autonomy (Allison et al., 2015). For instance, on the social crowdfunding platform Kiva, profit and risk-taking language decreases the attractiveness of microloans, whereas humanitarian language increases it (Allison et al., 2015). Business-related microloan requests, which can be related to entrepreneurial drive and the desire to grow the activity, are more likely to stimulate "external regulation” because such loans are more directly money-oriented (income generation and risk minimization). Business loans will use profit and risk-taking formulations that have been found to lower attractiveness, according to Allison et al. (2015).

These three arguments support the idea that, compared with the business purpose, the necessity purpose is more attractive to prosocially motivated crowdlenders and is thus more efficient for raising funds.

Hypothesis 1. Requests for basic necessity-purpose loans appeal more to prosocial crowdlenders than other types of loan.

The success of a prosocial crowdlending campaign may also be related to the size of the requested loan. Given the high information asymmetry between lenders and borrowers living far away from each other, lenders may be particularly cautious whenever they lend to microentrepreneurs they know very little about, especially those asking for riskier loans (Colombo et al., 2015). Moreover, no collateral is presented to crowdlenders (Khavul et al., 2009; Armendáriz \& Labie, 2011). This lack of collateral generates additional risks for lenders, who may thus adjust their investment behavior. One way to compensate for additional risks related to the absence of collateral is to adjust the size of the investment. It is indeed well known that smaller investments 
Business or basic needs?

require less collateral for various types of financial intermediary (Cowling \& Westhead, 1996). Consequently, lenders on social crowdfunding platforms may prefer microentrepreneurs who ask for smaller loans, which are considered less risky.

Moreover, non-business loans, such as basic necessity loans that do not generate any new revenue for borrowers, are even more likely to cause over-indebtedness and thus lead to default (Hudon, 2009). Indeed, investigating the variables that affect overindebtedness among microfinance borrowers in Ghana, Schicks (2014) found that those who took out loans for non-productive purposes were more likely to become overextended. From an SDT perspective, therefore, lenders who are aware of the risk of over-indebtedness may avoid supporting the largest loans that are not directly incomegenerating, and are thus less appropriate for poor clients (Armendáriz \& Labie, 2011). Indeed, large loans for basic necessities may reduce prosocially motivated microlenders' feelings of competence in the pursuit of their goal (i.e. helping others).

The effect of the loan's purpose might therefore vary according to the size of the requested loan. Lenders may prefer to avoid very large basic necessity loans that might increase the risk of over-indebtedness. Consequently, we may hypothesize that the size of the requested loan will moderate the effect of the loan's purpose on funds raised from prosocially motivated lenders.

Hypothesis 2. Requests for basic necessity-purpose loans appeal less to prosocial crowdlenders when the size of the loan increases.

\section{Hypotheses development: Gender and crowdfunding}




\section{Business or basic needs?}

While some recent papers have suggested that gender could significantly affect the success chances of crowdfunding campaigns (Alsos \& Ljunggren, 2017; Gafni et al., 2019), the influence of gender on the impact of the loan's purpose has not yet been studied in the context of microlending. Nevertheless, one can expect that the impact of the loan's purpose on the success chances of the campaign might vary according to the borrower's gender.

In the context of crowdfunding, the substantially larger number of potential contributors - compared with the limited number of banks—seems to play a part in “democratizing entrepreneurship” and female borrowers might encounter fewer social barriers than in other sectors (Kaufman et al., 2013). Empirical evidence tends to suggest that women suffer less discrimination (in relation to men) or none at all among the online crowd. Ravina (2008) and Duarte et al. (2012) found that women tended to be favored on the US online peer-to-peer lending platform Prosper.com. Studying the reward-based platform Kickstarter, Gafni et al. (2019) found that funding campaigns by female entrepreneurs outperformed those by their male counterparts, and that funders of both genders tended to support entrepreneurs of their own gender.

One can also expect that women would receive much more backing on prosocial crowdlending platforms. Indeed, referring to SDT, prosocially motivated crowdlenders are likely to prefer financing women since it will increase their feeling of competence in the pursuit of their goal (helping others). Microlending to women will increase the probability to have a strong social impact for three main reasons. First, women are likely to be poorer than men on average, due to various gender inequalities that make them more vulnerable to poverty (World Bank, 2011). Drivers of these disparities include gender norms, division of assets within households, work, and responsibility or 


\section{Business or basic needs?}

power relations (Grown, 2014). One of these important inequalities lies in access to finance. Female microentrepreneurs tend to have less access to financial services than male ones (Demirguc-Kunt et al., 2018), including access to informal sources such as moneylenders. Crowdlenders may thus prefer to lend to women since, even within the same household, they are likely to be poorer and more financially excluded than men.

Second, crowdlenders may prefer lending to women due to the empowerment effect of microloans. Providing women access to financial services may allow them to engage in income-generating activities to increase their earnings and eventually strengthen their decision-making power within the household and society (Zhang \& Posso, 2017). While the literature on the empowering effect of microloans is not totally conclusive, in some circumstances, lending to women may increase their personal empowerment (Garikipati, 2008) and decrease relational frictions inside households (Huis et al., 2019).

Third, another social motive to lend to women is related to their use of microloans and the impact this has on households. It is commonly accepted that women will be more closely involved in household activities and look after children more frequently than men but, also, that they will better manage their family's health and expenditure (Eddleston et al., 2016). This was partly confirmed by microfinance studies, such as Hermes \& Lensink (2011), who showed that women tended to invest more in sustainable goods or child education, and Garikipati (2008), who found that microloans to women were often diverted into enhancing households' assets and incomes, and that women would share the benefits with others in their household, especially their children.

This last argument introduces the gender moderating effect on loan purpose. More 
Business or basic needs?

precisely, we can assume that prosocially motivated microlenders will especially favor women when the loan is to finance basic necessities. As we have seen, basic necessity loans are more directly related to social motives or concerns, which may thus trigger the prosocial motivation of microlenders (Hypothesis 1). The gender (female) of poor entrepreneurs is also a classical proxy for social impact (Eddleston et al., 2016). Combining both will ensure the strongest social impact to microlenders who are willing to make a difference from a social perspective and, from an SDT perspective, will fulfill their need for perceived competence. We can thus expect that prosocially motivated microlenders, who prefer to invest in basic necessity loans, will also be more willing to lend to women in order to increase their social impact.

Hypothesis 3. Requests for basic necessity loans appeal even more to prosocial crowdlenders when entrepreneurs are female.

\section{Method}

\section{Sample}

Our sample was collected on Kiva, a crowdlending platform that has already been studied by other scholars (Allison et al., 2015; Moss et al., 2015; Ly \& Mason, 2012; Bradford, 2012, among others). This venture connects microfinance and crowdfunding, enabling entrepreneurs from impoverished parts of the world to crowdfund the microloans they need. Founded in 2005, Kiva has since emerged as one of the world's leading crowdfunding sites using the lending model (Bradford, 2012); its mission is "connecting people through lending to alleviate poverty". Once a loan request has been 
Business or basic needs?

posted, it has to be funded by the public within a month, or else no money will be transacted. If funding is obtained, the money is transacted to an intermediate MFI, which in turn transfers it to the borrower, who is expected to repay according to a prearranged schedule. For an example of a borrower's profile, see Figure 1.

We built a dataset of 767,679 loans with complete information that were posted on Kiva.org between its inception in March 2005 and December 31, 2017, using Kiva’s open public access API, a platform that enables information on loans and microfinance institutions (MFIs) to be downloaded. Out of those loans, only 64,949 failed to be funded within 31 days.

\section{Measurement of variables}

\section{Dependent variable}

In prior crowdfunding research (Galak et al., 2011; Allison et al., 2013; Allison et al., 2015; Moss et al., 2015), the variable of interest was typically the length of time (in days) needed for the loan to be fully funded, scaled from 1 day (i.e. the loan was funded within less than a day of being posted) to 31 days. If a loan is not funded within 31 days, it expires and no money is transacted. To take into account these two dimensions — being funded or not, and the time it takes to obtain funding — we opted for a survival analysis, similarly to Allison et al. (2015). This type of analysis jointly considers the two dimensions, combining them into one dependent variable, Time to Funding. 


\section{Business or basic needs?}

Although the borrower receives the same amount of money regardless of the time taken for the pledge to be funded, the number of days reflects the extent to which the lending crowd finds the loan attractive. A quickly funded loan might also have positive implications for the liquidity of the MFI and/or the borrower, who will receive the money sooner. If a loan is funded quickly, the MFI does not face the problem that arises in the opposite situation, as the time left to collect funding runs out.

\section{Independent variables}

The model includes several independent and control variables.

Business, Basic Necessities, and Other Consumption Loans: Every loan posted on Kiva is assigned to one economic sector and to one sub-sector (activity). We followed existing guidelines for previous microfinance loan classifications. As explained by Imai \& Azam (2010), business loans are those made for income-generating activities, for example, small-scale poultry farming or cattle rearing. Examples of business loan requests are: "Nancy from the Philippines asks for a loan to pay for additional supplies and merchandise products to sell in her direct-sales business." or "Yvelt from Haiti asks for a loan to pay for another machine for his production of bags.”

The second type of loan addresses a basic need of the borrower's household, such as medical expenses, school tuition, or repairs to the house. Here is an example of another consumption loan request: "Nada from Lebanon asks for a loan to pay for urgent medical tests she has to undergo.” The rest of the loans (third type) are requested to purchase more general consumer goods. Another example of another type of consumption loan request is: “Tolib from Tajikistan asks for a loan to purchase a wedding gift (furniture).” 
Based on these guidelines and definitions, we manually classified each of the 162 activities as either Business Loan, Basic Necessity Loan, or Other Consumption Loan. Similarly to standard practice (Alsos and Ljunggren, 2017), the same exercise was conducted by two of the authors separately as a robustness check ${ }^{3}$. To the best of our knowledge, such a detailed classification cannot be found in the existing literature.

Gender of the entrepreneur. Gender was provided in the data concerning single entrepreneurs, and whenever a team of borrowers was involved, the numbers of males and females in the group were provided. We then created a dummy variable for female entrepreneurs or female-majority groups (1) and male entrepreneurs or male-dominated groups (0). Groups with an equal number of men and women were not considered in the analysis. According to this classification, $73 \%$ of our initial sample was female. These numbers are consistent with the classification of Galak et al. (2011). We used the gender of the microentrepreneur as a proxy for the gender of the campaign. This approach is largely used in the literature on microentrepreneurs, as well as in the literature on crowdfunding (Périlleux \& Szafarz, 2015; Gafni et al., 2019; FigueroaArmijos \& Berns, 2019). However, it is clearly a shortcut. Indeed, authors have shown that linguistic styles used by female and male entrepreneurs on crowdfunding platforms differ and can influence funding success (Parhankangas et al., 2019). For example, using data from the Indiegogo platform, Gorbatai and Nelson (2015) have shown that female advantage on crowdfunding platforms is partially explained by differences between men and women in terms of the language they use. Moreover, Harrer and

\footnotetext{
${ }^{3}$ To a large extent, the two coders allocated loan activities in the same way. The few items that were not coded similarly were discussed with the third author.
} 
Business or basic needs?

Lehner (2019) have identified tropes and associated feminist themes driving the success of female entrepreneurs' campaigns on crowdfunding platforms by connecting with immanent societal values.

Competition controls. In their paper, Ly \& Mason (2011) highlighted the importance of the competition effect when fundraising on Kiva. Even highly attractive loans would go unnoticed when posted on the platform due to the high number of other loans that were fundraising at the same time. The lenders' funds are limited, as is exposure on the platform. Nonetheless, competition may also carry some benefits, such as a greater focus on microfunding in certain regions or sectors, or funding through a popular MFI partner. Therefore, we added the four competition controls computed by Ly \& Mason (2011): I. The number of other loans by the same MFI that were fundraising on the day the loan was posted. II. The number of other loans in the same region that were fundraising on the day the loan was posted ${ }^{4}$. III. The number of other loans in the same sector that were fundraising on the day the loan was posted. IV. The share of female entrepreneurs fundraising on the day the loan was posted.

Further control variables. Other relevant control variables were added to the regression, on the basis of previous research including works by Allison et al. (2013), Galak et al. (2011), and Moss et al. (2015). First, we added a dummy variable for each world region. We also controlled for the requested amount of the loan (logged) and the riskiness of the MFI (as measured by 0 to 4.5 stars, rated by Kiva), and added a dummy for groups ( 1 for group, 0 for individual). All of these control variables might affect the Kiva user making his or her lending decision.

\footnotetext{
${ }^{4}$ The eight world regions are determined by Kiva.
} 


\section{Analysis}

Since our dependent variable is Time to Funding, our method was selected among the survival analysis techniques. Survival analysis is used in cases where the sample tracks individuals until an event happens or they are lost from the data set. The interesting aspects are the length of time they "survive” in the sample before they exit (in our case: are funded), and in the risk of exiting, which is the hazard rate. Both depend on the main regressors and the co-variates.

Previous studies that researched shorter time spans of the Kiva data set, such as Galak et al (2011) and Moss et al (2015), used the Cox proportional hazards model (Cox, 1972) for their empirical analysis, with “time to get funded” as their right-censored dependent variable. This statistical model takes into consideration the time until an event of interest occurs, and compares the cumulative probability of events over time for two or more cohorts, while adjusting other influential covariates (Singh \& Mukhopadhyay, 2011). However, the proportional hazard assumption, which is valid in the Cox model, is violated in our dataset, which spans over twelve years.

Therefore, we used a fully parametric hazard model with Weibull distribution, which fitted our data. Although the output of this model is hazard ratios obtained by exponentiating beta values (e $\beta)$, we present them as coefficients $(\beta)$ for the convenience of our readers.

The risk of endogeneity has been largely addressed. Indeed, measurement error is strongly limited since input data was directly collected from the platform. Concerning omitted variables, we included all control variables that are generally used in the 


\section{Business or basic needs?}

literature in the regressions. Finally, concerning reverse causality, we suggest that preferences are intrinsically defined and will not be influenced by external elements.

As robustness checks, we conducted three matching analyses for each of our three hypotheses. First, referring to the first hypothesis (H1), we matched loans one-to-one according to loan status, gender of borrower, year, country, exact loan amount, percentiles of number of competing loans in the same sector and the same world region, MFI rating (in integer numbers), and loan terms such as: currency exchange loss (at the expense of the borrower/MFI/shared), bonus credit eligibility, and repayment interval. The only difference between matched loans is their purpose (business versus basic necessities, excluding other consumption loans). In cases where two or more loans had the exact same characteristics, we randomly selected only one of them. This process left us with a subsample of 865 matched pairs ${ }^{5}$. We computed the difference in Time to Funding within each matched couple. Since both members of the couple shared the same characteristics, except for purpose, we were able to deduce that any difference that might exist would result from that particular characteristic. We ran $t$ tests on Time to Funding in this subsample, to determine whether this is different between business and basic necessities loans. Second, to test the robustness of the results we obtained for the second hypothesis, we divided the subsample into two groups: lower versus higher than the median. We then tested to what extent differences in Time to Funding between business and basic necessity loans depend from the size of the loans.

\footnotetext{
${ }^{5}$ With this exact-matching process, we sought to find campaigns that were as similar as possible by controlling for multiple dimensions, including: both campaigns raising the exact same amount (to the dollar) and the same percentile of number of competing loans in the same sector and world region. This very precise matching increases the validity of the results, yet comes at the cost of reducing the sample size. However, although the sample may seem small compared to the whole dataset used in this paper, it is still a large sample that leaves us with high enough power for computing robust statistical tests.
} 
The third matching analysis concerns hypothesis H3: we matched fully-funded loans according to the same characteristics as before, the difference, this time, being the gender of the entrepreneur, while the purpose was added to the matching dimensions. The subsample we obtained consisted of 30,798 matched couples. We then checked for differences between the two groups ${ }^{6}$.

\section{Results}

\section{Main results}

Table 1 provides the descriptive statistics and correlations of our variables. We can see that, on average, it takes 12 days for a loan to get funded. The vast majority of the loans granted (88\%) are for business use. The average loan size is US\$633, and 73\% of the requests come from female entrepreneurs. Correlations do not exceed 0.8, which prevents multicollinearity issues (Kennedy, 2008).

< Insert Table 1 here >

Table 2 presents the regression results for the aforementioned specifications (coefficients and standard errors in parentheses).

$<$ Insert Table 2 here $>$

We started by running a regression over the basic variables of interest: the purpose of the loan (with basic necessity loans being the omitted category), its size, and the gender

\footnotetext{
${ }^{6}$ We do not present a matching analysis for the effect of size on the dependent variable, since it is not relevant in this setting. However, the results can be provided on request.
} 


\section{Business or basic needs?}

of the entrepreneur. We also added competition controls and dummies for groups, rating of the MFI, and region (Model 1). To this basic setup, we added interaction dummies (2 and 3). Specification 4 includes all of these variables together. The minor changes in AIC and BIC values suggest that adding additional variables did not cause any loss of information to our estimations.

Our first hypothesis supports the notion that a request for a basic necessity loan better responds to the prosocial motivation of microlenders and will thus be associated with a quicker funding than a request for a business loan or for other consumption (H1). Our results confirm this hypothesis. We obtained a positive and significant coefficient associated with the business dummy and the other consumption dummy ( $\beta=0.13$ and 0.27 respectively, $p=.01$ in regression (1)), which suggests that these loans require more time for full funding than basic necessity loans. All other things being equal, the hazard of loan fulfillment decreased when the request concerned basic necessity purposes. Hence, microlenders are more willing to support microentrepreneurs who highlight their fundamental needs rather than their willingness to invest in business activities.

We also found support for the second hypothesis, which stated that the size of the loan would moderate the effect of loan purpose on the duration of the fundraising campaign (H2). Indeed, a larger loan size does moderate the positive effect of business purpose (which increases the time needed to obtain funding), since the coefficient associated with the interaction term is negative $(\beta=-0.19, p=.005$ in regression (2)). This result also means that the comparative advantage of basic necessity loans over business loans decreases when loan size increases. 
As regards the gender effect, we first found — as expected — that female entrepreneurs were funded more quickly than their male counterparts $(\beta=-0.48, p=.003$ in regression (1)). This result is consistent with previous studies on social crowdlending, which also uncovered a gender advantage for female entrepreneurs (Galak et al., 2011; Moss et al., 2015).

Our third hypothesis (H3) stated that gender would moderate the loan purpose effect on fundraising. In particular, H3 holds that basic necessity loans are funded even faster when requested by a female borrower. Our findings support H3. Indeed, results show that female borrowers not only enjoy a comparative advantage for basic necessity loans, but also an absolute advantage for both types of loan (basic necessity and business). Regression (3) shows that basic necessity loans, when requested by female borrowers, are funded significantly more rapidly than when requested by male borrowers (which is the referred category), since the associated coefficient is negative and significant $\left(\beta_{\text {Female }}=-0.54, p=.007\right)$. Regression (3) also shows that business loans requested by female borrowers $\left(\beta_{\text {business }}=0.09+\beta_{\text {Female }}=-0.54+\beta_{\text {Female*Business }}=0.06\right)$ are funded more rapidly than business loans requested by male borrowers $\left(\beta_{\text {business }}=0.09\right.$ ). However, the comparative advantage of female borrowers is stronger when they ask for a basic necessity loan, since the coefficient associated with the interaction variable is positive and significant $\left(\beta_{\text {Female*Business }}=0.06, p<.008\right)^{7}$.

\footnotetext{
${ }^{7}$ Compared to the baseline (a male borrower asking for a basic necessity loan), the coefficient associated with a male borrower asking for a business loan is, as expected, significantly higher ( $\beta_{\text {Business }}=0.09, p=$ 0.011).
} 
Business or basic needs?

Finally, regarding control variables, we found that loans intermediated by safer MFI partners were funded more quickly than others. This finding is consistent with Allison et al. (2015) and with intuition, but inconsistent with Galak et al. (2011) and Moss et al. (2015). We also found similar results concerning the competition variables in previous studies (Ly and Mason, 2012). Moreover, the coefficient for group loans is consistently negative across the specifications, suggesting that they are more attractive to lenders than applications from individual borrowers.

\section{Robustness checks}

In order to verify the validity of our results, we ran our three robustness checks using matching methods, presented in Table 3.

$<$ Insert Table 3 here $>$

\section{Matching for Loan Purpose Effect}

We computed the difference in Time to Funding between each half of matched couples, and found that basic necessity loan campaigns were funded faster $(M=5.31, S D=0.29)$ than business loans $(M=5.9, S D=0.31)$, meaning that a fundraising campaign for a business loan was nearly $10 \%$ longer on average, and statistically significant $(t(1,728)$ $=-1.385, p=.083$, see Panel A). These results validate previous findings supporting H1.

\section{Matching for Loan Size Moderation Effect}

We then divided the aforementioned subsample into two groups: lower versus higher than the median. We can see that the difference in Time to Funding between basic 
Business or basic needs?

necessity and business loans is significant where we considered loans below or equal to the median value of $\$ 675(t(1,106)=1.311, p=.095$ whereas the difference is not significant where we only considered loans above the median $(t(620)=-0.691, p=$ .245). These results support our finding that loan size is taken into consideration by lenders when deciding whether to fund basic necessity loans.

\section{Matching for Gender Moderation Effect}

The difference in the number of funding days between male $(M=11.38, S D=0.07)$ and female borrowers $(M=6.77, S D=0.06)$ was 4.62 in favor of females, whose loans were funded significantly faster $(t(61,594)=54.44, p<.001$, see Panel B). Looking at basic necessity loans only, the difference increased to 4.96 days. However, when the purpose of the loan was business investment, the difference decreased to 4.56 days (significantly lower than 4.96). Computing the t tests over the number of funding days in the subsample, all three differences came out as significant $(p<.001)$. Therefore, this result confirms previous findings, supporting H3, suggesting that when a female entrepreneur is involved, the lender's funding preference for a basic necessity loan is stronger than for a business loan.

\section{Discussion}

The crowdfunding phenomenon keeps growing and revolutionizing how entrepreneurs raise capital; hence it is vitally important to have in-depth knowledge about the way microlenders make decisions (Allison et al., 2015; Chan \& Parhankangas, 2017; Berns et al., 2020). Our study gives new insights into the factors affecting the success chances of prosocial crowdfunding campaigns for microentrepreneurs in developing countries. Our empirical results are threefold. 
First, they show that a microlender will be more likely to support impoverished entrepreneurs who ask for loans to meet social needs rather than to fund business investment. Necessity loans, requested to cover expenses made to meet basic human needs, are related to the critical situation faced by the microentrepreneur, and the lender heeds the call for help. Referring to SDT, lenders' preference for this type of loan can be explained by prosocial motivation. Support for basic necessity loans stimulates relatedness, one of the three basic psychological needs, which tend to increase prosocial motivation relatedness, one of the three basic psychological needs, which tends to increase prosocial motivation?. Our results echo the findings of Allison et al. (2015), i.e. that narratives on social lending platforms highlighting the venture as an opportunity to help others are more successful that those framed as a business opportunity. Socially-oriented lending platforms such as Kiva offer a perfect outlet for microlenders willing to provide support to impoverished citizens.

Our second finding is that loan purpose and loan size have a moderating effect on the duration of the fundraising campaign, since this pattern holds especially for small loans. It is well known that the likelihood of success of the crowdfunding campaign decreases as the size of the campaign's target capital increases (Buttice et al., 2017). Our results shed new light on the effect of loan size. The most plausible interpretation of this moderating effect is the microlenders' desire to avoid the potentially negative consequences of large loans, such as over-indebtedness, especially since loans for social needs do not generate any new income. Referring to SDT, this would increase prosocially motivated microlenders' feelings of competence. 


\section{Business or basic needs?}

Finally, we can observe a gender effect. Consistent with the literature (Ravina, 2008; Duarte et al., 2012; Gafni, et al., 2019), our results suggest a preference toward female entrepreneurs on the platform. This finding is in keeping with the socially-minded motives described above, since female-headed households are over-represented among the poor, according to a meta-analysis by Buvinić and Gupta (1997). It is also in line with standard practice in microfinance, since most MFIs explicitly or implicitly focus on women (D’Espallier et al., 2011).

In the context of prosocial crowdfunding, the results concerning the gender moderating effect on the type of loan are particularly original. In particular, although females enjoy an absolute advantage, we show that their comparative advantage is significantly lower for a business loan than for a basic necessity loan. In line with SDT, prosocially motivated microlenders prefer to lend to women for basic necessities, since they view this type of loan as having the strongest social impact. It increases their feelings of competence.

The gender moderating effect, however, can have adverse consequences, inducing women to ask for basic necessity loans and driving them away from business. In essence, this reveals an ethical blind spot. Indeed, prosocially motivated microlenders may unintentionally end up producing outcomes that go against their ethical values (Sezer et al., 2015; Pittarello et al., 2015). Sezer et al. (2015, p. 7) have identified three sources of ethical blind spots. The first one is temporal distance from an ethical dilemma — when people overestimate their ethical behavior in the future. The second one is related to bias that leads people to disregard others' unethical behavior. This bias tends to undermine moral agency in work organizations. For instance, Moberg (2006) 


\section{Business or basic needs?}

shows that supervisors are likely to encounter ethical blind spots when they evaluate their subordinates' ethical behavior, leading to inadequate control.

A last type of ethical blind spot is due to implicit biases. In this case, people willing to do good are not aware of the possible negative implications that their decisions may have (Nayebpour \& Koehn, 2003; Bazerman \& Sezer, 2016) ${ }^{8}$. As stressed by Palazzo et al. (2012, p. 323), in this type of ethical blind spot, "people might behave unethically without being aware of it”. The ethical blind spot revealed by our study stems from an implicit bias, since crowdlenders were not aware of the possible adverse consequences of their behavior.

Consequently, this paper links ethical blind spot with prosocial motivation theory, which is an innovative approach. Indeed, our findings suggest that combining various prosocial motives could lead to some counter-productive effects from a prosocial perspective and eventually produce an ethical blind spot. Prosocial motives may not always reinforce each other, which could lead to a trade-off among them. This paper adds to the literature discussing possible tensions between the different social missions that social enterprises can pursue, in addition to the classical tensions between economic and social missions (Defourny \& Nyssens, 2017; Dufays, 2019).

Our results make three main research contributions and have a number of implications for practice. First, they enrich SDT theory by looking at the purpose of the loan as a motivation factor of prosocial crowdfunding. They show that loan purpose has a significant impact on decisions of prosocially motivated lenders to make loans to

\footnotetext{
${ }^{8}$ Nayebpour \& Koehn (2003) call upon this concept, for example in the case of total quality management (TQM), since TQM's customer focus may result in other key stakeholders being ignored.
} 


\section{Business or basic needs?}

microentrepreneurs in developing countries. To the best of our knowledge, this element had not been investigated in this context before. Our findings may encourage crowdfunding platforms to publish more information on loan purpose or to include more projects from microentrepreneurs focusing on essential necessities and social needs. Although they are very popular, these loans constitute a small minority. The findings also highlight the importance of a moderating effect in terms of interaction with loan size. They confirm other studies (Alsos \& Ljunggren, 2017; Gafni, et al., 2019) showing that gender affects the crowdfunding decisions of impact lenders.

Second, our paper contributes to the ethical finance literature and expands prosocial theory by looking into a crowdlending context. We provide new empirical evidence on the factors that encourage investors to finance underserved microentrepreneurs. In developing countries, these tend to develop their own enterprises and, in doing so, to create varying degrees of economic and social value (Moss et al., 2015). In particular, our findings suggest that the pattern observed on a well-established prosocial crowdlending platform runs counter to the widely shared guidelines of some MFIs, which prefer to fund productive loans. This important finding is in line with some recent studies on crowdfunding in other industries.

Our research also shows that the democratization of funding decisions, which are no longer in the hands of experts alone, alters the type of project supported. This democratization leads to an increase in the probability of socially valued projects being

financed (Defazio et al,, 2020; Mollick \& Nanda, 2015; Younkin \& Kuppuswamy, 2018; Tchakoute-Tchuigoua, 2018). 


\section{Business or basic needs?}

Third, our paper contributes to the literature on gender and business ethics, and finds evidence of an ethical blind spot in the social crowdlending context. It shows that, in this specific context, female entrepreneurs will receive greater rewards from prosocial investors than their male counterparts do, whatever the circumstances. This is in line with other studies on crowdfunding, which show that this more democratic way of financing entrepreneurs tend to be a less discriminatory path to funding for women (Galak et al., 2011; Moss et al., 2015). However, their comparative advantage is even greater when they conform to their traditional social role. In a way, this result partly contradicts the findings of a study by Greenberg \& Mollick (2017) about a rewardbased crowdfunding platform. The authors showed that female entrepreneurs outperformed their male counterparts, especially in male-dominated technological categories, thanks to the homophily-related activism of female backers.

Our study obviously has some limitations, and we would like to stress three of them. The first one concerns the generalizability of our findings. We conducted our analysis on a clearly prosocially driven platform, which had a sizeable advantage-we were sure that lenders on this platform were prosocially motivated. Consequently, we were fully aware that we observed the specific behavior of prosocially motivated microlenders. There was no doubt about their prosocial motivations, since the platform did not pay any interest rate on the loans granted. However, this has its disadvantages as well. In particular, we could not compare the behavior of these microlenders with the behavior of microlenders who were not prosocially motivated.

The second limitation concerns our proxies. More particularly, we used the gender of the microentrepreneur as a proxy for the gender of the campaign. This approach is 
Business or basic needs?

widespread in the literature on microentrepreneurs, as well as in the literature on crowdfunding (Figueroa-Armijos \& Berns, 2019). However, it is clearly a shortcut. Indeed, Gorbatai and Nelson (2015), Parhankangas et al. (2019) and Harrer and Lehner (2019) show that female and male entrepreneurs do not present their projects in the same way and that there is a clear link between feminist tropes and crowdfunding success.

The third limitation is related to the fungibility of money. Although microentrepreneurs apply for a loan for a specific purpose, they can always use the money for a different objective. We can never be sure that the money granted will indeed be used for the purpose stated by the microentrepreneur. This, however, should not introduce too much bias into our analysis, since it still reveals microlenders’ preferences.

\section{Conclusion}

Access to funding is both crucial and problematic for many microentrepreneurs. For this reason, we analyzed the impact of the type of loan on fundraising outcomes on a prosocial crowdlending platform. Our findings suggest that loans related to basic needs are funded faster than loans for business, especially when small amounts are involved. Moreover, we found that female borrowers were funded faster, especially when they applied for loans to meet essential needs. Thus, there is a gender moderating effect.

Prosocial crowdlending is a new way of raising funds to finance poor microentrepreneurs. Our results show that, for microfinance organizations, prosocial crowdfunding has the potential to lead to diversification by increasing the social impact 


\section{Business or basic needs?}

of the microfinance sector. The trend toward commercialization within this sector has frequently been criticized, for it is pushing it toward a market-based logic (Khavul et al., 2013) and, over time, displacing the field's foundational principles of poverty alleviation and economic development (Kent \& Dacin, 2013). However, microlenders active on crowdfunding platforms primarily finance small loans and female entrepreneurship, two proxies that are very frequently used to assess the social performance of MFIs (Cull et al., 2009; Périlleux \& Szafarz, 2015). Consequently, although the practice of prosocial crowdlending to support microentrepreneurs is at an early stage of development, it seems to be nudging the microfinance sector along a social path and could thus partly counterbalance some of the potential drawbacks and ethical concerns of commercialization. Our results, however, suggest an ethical blind spot, since prosocially motivated crowdlenders may unintentionally end up producing adverse outcomes, driving women away from business.

Future research may be able to identify additional moderators that affect the impact of loan purpose on lending success. In particular, linguistic styles used by female and male microentrepreneurs, and the coherence between their linguistic style and the purpose of the requested loan, could be added to the analysis. Moreover, gender differences concerning other types of loan or funding tool for (micro)entrepreneurs could also be tested.

Another interesting extension would be to cross-tabulate these results with lenders' characteristics in order to identify those that are correlated with a preference for a specific loan purpose. The research reported on in this paper assessed the average preferences of prosocially motivated microlenders. However, these preferences might 
Business or basic needs?

vary according to lenders' characteristics, in particular the gender of microlenders, since it is known that gender affinity and homophily can play a role on crowdfunding platforms (Greenberg \& Mollick, 2017; Vismara et al., 2017; Gafni et al., 2019). This could also be investigated in the context of prosocially motivated crowdfunding.

Finally, lending by the crowd is only one type of crowdfunding. It would be interesting to discover the extent to which results obtained in connection with prosocial crowdlending are similar to those obtained following a similar analysis in other prosocial crowdfunding contexts, such as prosocial reward-based or prosocial equitybased crowdfunding. This could provide some insights into the ways in which the funding method influences prosocial preferences and the presence of ethical blind spots. We hope that future studies will address these issues and shed some light on them.

\section{Compliance with Ethical Standards:}

This article does not contain any studies with human participants or animals performed by any of the authors. 


\section{Bibliography}

Afuah, A. \& Tucci, C. (2012). Crowdsourcing as a Solution to Distant Search. Academy of Management Review, 37(3), 355-375.

Agrawal, A. K., Catalini, C., \& Goldfarb, A. (2011). The Geography of Crowdfunding (No. w16820). National bureau of economic research.

Ahlers, G. K.C., Cumming, D., Günther, C. \& Schweizer, D. (2015). Signaling in Equity Crowdfunding. Entrepreneurship Theory and Practice, 39(1), 955-980.

Aldohni, A.K. (2018), Is Ethical Finance the Answer to the Ills of the UK Financial Market? A Post-Crisis Analysis, Journal of Business Ethics, 151, 265 -278.

Allison, T. H., Davis, B. C., Short, J. C., \& Webb, J. W. (2015). Crowdfunding in a Prosocial Microlending Environment: Examining the Role of Intrinsic Versus Extrinsic Cues. Entrepreneurship Theory and Practice, 39(1), 53-73.

Allison, T.H., McKenny, A.F., \& Short, J.C. (2013). The effect of entrepreneurial rhetoric on microlending investment: An examination of the warm-glow effect. Journal of Business Venturing, 28(6), 690-707.

Alsos, G.A. \& Ljunggren, E. (2017). The Role of Gender in Entrepreneur -Investor Relationships: A Signaling Theory Approach. Entrepreneurship Theory and Practice, 41(4), 567-590.

André, K., Bureau, S., Gautier, A., \& Rubel, O. (2017). Beyond the Opposition between Altruism and Self-interest: Reciprocal giving in reward-based crowdfunding. Journal of Business Ethics, 146, (2), 313-332.

Armendáriz, B. \& M. Labie (2011), The Handbook of Microfinance, LondonSingapore: Scientific Work.

Ashta, A., Assadi, J. \& Marakkath, N. (2015), The Strategic Challenges of a Social Innovation: The Case of Rang De in Crowdfunding, Strategic Change, 24, 1-14.

Baierl, R., Behrens, J., \& Brem, A. (2019). Digital Entrepreneurship. Springer.

Barigozzi, F., Tedeschi, P. (2019). On the credibility of ethical banking, Journal of Economic Behavior \& Organization, 166, 381-402,

Bagozzi, R.P. and Dholakia, U. M. (2006). Open Source Software User Communities: A Study of Participation in Linux User Groups. Management Science, 52(7), 10991115.

Battilana, J. \& Dorado, S. (2010) Building sustainable hybrid organizations: the case of commercial microfinance organizations, Academy of Management Journal, 53(6), 
pp. 1419-1440.

Bauwens, T., Huybrechts, B., Dufays, F. (2019). Understanding the diverse scaling strategies of social enterprises as hybrid organizations: The case of renewable energy cooperatives. Organization \& Environment, 10.1177/1086026619837126.

Bazerman M. H. \& Sezer (2016). Bounded awareness: Implications for ethical decision making. Organizational Behavior and Human Decision Processes, 136, 95-105. Belleflamme, P., Lambert, T., \& Schwienbacher, A. (2014). Crowdfunding: Tapping the Right Crowd. Journal of Business Venturing, 29(5), 585-609.

Belleflamme, P., Omrani, N., \& Peitz, M. (2015). The economics of crowdfunding platforms. Information Economics and Policy, 33, 11-28.

Bendell, B. L. (2017). I don’t Want to be Green: Prosocial Motivation Effects on Firm Environmental Innovation Rejection Decisions. Journal of Business Ethics, 143, 277288

Berns, J. P., Figueroa-Armijos, M., da Motta Veiga, S. P., \& Dunne, T. C. (2020). Dynamics of lending-based prosocial crowdfunding: Using a social responsibility lens. Journal of Business Ethics, 161(1): 169-185.

Bradford, S.C. (2012). Crowdfunding and the Federal Securities Laws, Columbia Business Law Review, 1, 1-150.

Brolis, O. \& Nyssens, M. (2019). Does the Mission of an Organization Affect the Quality of Low-Skilled Jobs in Quasi-markets?: A Comparison Between Social Enterprises and For-Profit Organizations. Voluntas. https://doi.org/10.1007/s11266019-00164-X

Bruton, G., Khavul, S., Siegel, D. \& Wright, M. (2015). New financial alternatives in seeding entrepreneurship: Microfinance, crowdfunding, and peer-to-peer innovations. Entrepreneurship Theory and Practice, 39(1) 9-26.

Bruton, G.D., Khavul, S. \& Chavez, H. (2011). Microfinance in emerging economies: Building a new line of inquiry from the ground up. Journal of International Business Studies, 42(5), 718-739.

Burtch G., Ghose, A., Wattal, S. (2015). The Hidden Cost of Accomodating Crowdfunder Privacy Preferences: A Randomized Field Experiment. Management Science. 61(5), 949-962.

Buttice, V., Colombo, M. G., \& Wright, M. (2017). Serial crowdfunding, social capital, and project success. Entrepreneurship Theory and Practice, 41(2), 183-207. 
Buvinić, M., \& Gupta, G. R. (1997). Female-headed households and female-maintained families: are they worth targeting to reduce poverty in developing countries?. Economic Development and Cultural Change, 45(2), 259-280.

Carter, S., Shaw, E., Wilson, F. \& Lam, W. (2007), Gender, entrepreneurship and bank lending: the criteria and processes used by bank loan officers in assessing applications, Entrepreneurship Theory \& Practice, 31(3), 427-44.

Cholakova, M., \& Clarysse, B. (2015). Does the Possibility to Make Equity Investments in Crowdfunding Projects Crowd Out Reward-Based Investments? Entrepreneurship Theory and Practice, 39(1), 145-172.

Collins, L. \& Pierrakis, Y. (2012) The venture crowd: crowdfunding equity investments into business. (Project Report) London, U.K.: NESTA. 36 p.

Collins, D., Morduch, J., Rutherford, S. \& Ruthven, O. (2009). Portfolios of the Poor: How the World's Poor Live on \$2 a Day. Princeton University Press: New Jersey.

Colombo, M.G., Franzoni, C. \& Rossi-Lamastra, C. (2015). Internal Social Capital and the Attraction of Early Contributions in Crowdfunding. Entrepreneurship Theory and Practice, 39(1), 75-100.

Conger, M., McMullen, J. S., Bergman Jr, B. J., \& York, J. G. (2018). Category membership, identity control, and the reevaluation of prosocial opportunities. Journal of Business Venturing, 33(2), 179-206.

Cornée, S. \& Szafarz, A. (2014). Vive la Différence: Social Banks and Reciprocity in the Credit Market. Journal of Business Ethics. 125, 361-380.

Cox, D.R. (1972). Regression models and life tables. Journal of the Royal Statistical Society, 34, 187-220.

Cowling, M., \& Westhead, P. (1996). Bank lending decisions and small firms: does size matter?. International Journal of Entrepreneurial Behavior \& Research, 2(2), 5268.

Cumming, D., Hou, W., \& Lee, E. (2016). Sustainable and ethical entrepreneurship, corporate finance and governance, and institutional reform in China. Journal of business ethics, 134(4), 505-508.

De Cooman, R., De Gieter, S., Pepermans, R., \& Jegers, M. (2011). A Cross-Sector Comparison of Motivation-Related Concepts in For-Profit and Not-For-Profit Service Organizations, Nonprofit and Voluntary Sector Quarterly, 40(2) 296-317. 
Defazio, D., Franzoni, C., \& Rossi-Lamastra, C. (2020). How Pro-social Framing Affects the Success of Crowdfunding Projects: The Role of Emphasis and Information Crowdedness. Journal of Business Ethics, 1-22.

Defourny, J. \& Nyssens, N. (2017). Fundamentals for an International Typology of Social Enterprise Models. Voluntas, 28(6), 2469-2497.

Demirguc-Kunt, A., Klapper, L., Singer, D., Ansar, S., \& Hess, J. (2018). The Global Findex Database 2017: Measuring Financial Inclusion and the Fintech Revolution. The World Bank.

D’Espallier, B., Guérin, I., \& Mersland, R. (2011). Women and repayment in microfinance: A global analysis. World Development, 39(5), 758-772.

Dorfleitner, G., Oswald, E. M., \& Röhe, M. (2019). The access of microfinance institutions to financing via the worldwide crowd. The Quarterly Review of Economics and Finance.

Dorfleitner, G., Hornuf, L., \& Weber, M. (2018). Dynamics of investor communication in equity crowdfunding. Electronic Markets, 28(4), 523-540.

Duarte, J., Siegel, S. \& Young, L. A. (2012), Trust and Credit: The Role of Appearance in Peer-to-peer Lending. Review of Financial Studies, 25 (8): 2455-2484. Eddleston, K. A., Ladge, J. J., Mitteness, C. \& Balachandra, L. (2016). Do You See What I See? Signaling Effects of Gender and Firm Characteristics on Financing Entrepreneurial Ventures. Entrepreneurship Theory and Practice, 40(3), 489-514.

Figueroa-Armijos, M., \& Johnson, T. G. (2016). Entrepreneurship policy and economic growth: Solution or delusion? Evidence fro a state initiative Small Business Economics, 47(4), 1033-1047.

Figueroa-Armijos, M._and Berns, J. (2019) Vulnerable Populations and Entrepreneurship in Prosocial Crowdfunding: Do Gender \& Location Matter? Academy of Management Proceedings, 1, 15350

Fleming, L. \& Sorenson, O. (2016), Financing by and for the masses: An introduction to the special issue on crowdfunding. California Management Review, 58, 5-19 Gafni, H., Marom, D., Robb, A., \& Sade, O. (2019). Gender dynamics in crowdfunding (Kickstarter): Evidence on entrepreneurs, investors, deals and taste-based discrimination.

Galak, J., Small, D., \& Stephenson, A.T. (2011). Microfinance decision making: A field study of prosocial lending. Journal of Marketing Research, 48 (Special Issue), S130S137. 
Garikipati, S. (2008). The impact of lending to women on household vulnerability and women’s empowerment: evidence from India. World development, 36(12), 2620-2642. Gorbatai, A. D. and Nelson, L. (2015). Gender and the Language of Crowdfunding. Academy of Management Proceedings, 1, 15785.

Grant, A. M. (2007). Relational job design and the motivation to make a prosocial difference. Academy of Management Review, 32(2), 393-417.

Grant, A. M. (2008). Does Intrinsic Motivation Fuel the Prosocial Fire? Motivational Synergy in Predicting Persistence, Performance, and Productivity. Journal of Applied Psychology, 93(1), 48-58.

Grant, A. M. and Berry, J. W., (2011). The necessity of others is the mother of invention: Intrinsic and prosocial motivations, perspective taking, and creativity. The Academy of Management Journal. 54(1), 73-96.

Greenberg, J., \& Mollick, E. R. (2017). Activist Choice Homophily and the Crowdfunding of Female Founders. Administrative Science Quarterly.

Grown, C. (2014). Missing women: Gender and the extreme poverty debate. Learning Lab, United States Agency for International Development, Washington, DC.

Guenther, C., Johan, S., \& Schweizer, D. (2018). Is the crowd sensitive to distance?how investment decisions differ by investor type. Small Business Economics, 50(2), 289-305.

Harrer, T. and Lehner, O. M. (2019). Crowdfunding and Societal Change: A Critical Feminist Perspective on Entrepreneurial Discourse. Academy of Management Proceedings, 1, 10657.

Hermes, N. \& Lensink, R. (2011). Microfinance: Its Impact, Outreach, and Sustainability. World Development. 39(6), 875-881.

Hildebrand, T., Puri, M., \& Rocholl, J. (2017) Adverse Incentives in Crowdfunding. Management Science 63(3), 587-608.

Hudon, M. (2009). Should Access to Credit be a Right?, Journal of Business Ethics, 84, 17-28.

Hudon, M., Labie, M., \& Reichert, P. (2020). What is a fair level of profit for social enterprise? Insights from microfinance. Journal of Business Ethics, 162, 627-644.

Huis, M., Lensink, R., Vu, N., \& Hansen, N. (2019). Impacts of the Gender and Entrepreneurship Together Ahead (GET Ahead) training on empowerment of female microfinance borrowers in Northern Vietnam. World Development, 120, 46-61. 
Imai, K. S., \& Azam, M. S. (2012). Does Microfinance Reduce Poverty in Bangladesh? New Evidence from Household Panel Data. Journal of Development Studies, 48(5), 633-653.

Johnston, J., \& Morduch, J. (2008). The Unbanked: Evidence from Indonesia. World Bank Economic Review, 22(3), 517-537.

Kappel, T. (2009). Ex ante crowdfunding and the recording industry: A model for the U.S.?. Entertainment Law Review, 3(3), 375-385.

Kaufman, Z. D., Kassinger, T. W., \& Traeger, H. L. (2013). Democratizing entrepreneurship: An overview of the past, present, and future of crowdfunding. Bloomberg BNA Securities Regulation \& Law Report, 45(5), 208-217. Khavul, S., Bruton, G.D., \& Wood, E. (2009). Informal family business in Africa. Entrepreneurship Theory and Practice. 33(6), 1219-1238.

Khavul, S., Chavez, H., \& Bruton, G.D. (2013). When institutional change outruns the change agent: The contested terrain of entrepreneurial microfinance for those in poverty. Journal of Business Venturing. 28(1), 30-50.

Kennedy, P. (2008) A Guide to Econometrics. $6^{\text {th }}$ Edition, Wiley-Blackwell.

Lehner, O.M. 2013. Crowdfunding Social Ventures: A Model and Research Agenda. Venture Capital, 15(4): 289-311.

Lehner, O.M. 2014. The formation and interplay of social capital in crowdfunded social ventures. Entrepreneurship and Regional Development, 26(5-6): 478-499.

Lehner, O. M., \& Harrer, T. (2019). Crowdfunding Platforms as Focal Actors in an Entrepreneurial Ecosystem: An Interdisciplinary Value Perspective. Proceedings of the 52nd Hawaii International Conference on System Sciences.

Lehner, O. M., \& Harrer, T. (2019). Crowdfunding revisited: a neo-institutional fieldperspective. Venture Capital, 21(1), 75-96.

Ly, P., \& G. Mason. (2011). Competition between Microfinance NGOs: Evidence from Kiva. World Development, 40(3), 643-655.

Massolution (2016). 2015CF: Crowdfunding Industry Report. Retrieved from: http://www.crowdsourcing.org/editorial/global-crowdfunding-market-to-reach-344bin-2015-predicts-massolutions-2015cf-industry-report/45376

McKenny, A. F., Allison, T. H., Ketchen Jr, D. J., Short, J. C., \& Ireland, R. D. (2017). How should crowdfunding research evolve? A survey of the entrepreneurship theory and practice editorial board. Entrepreneurship Theory and Practice, 41(2), 291-304. 
Mitra, P., Hermans, J., Janssen, F. and Kickul, J. R. (2019). Social Entrepreneurship and Crowdfunding: The Importance of Rewards and Prosocial Motivation. Academy of Management Proceedings, 1, 18159.

Moberg, D. J. (2006). Ethics Blind Spots in Organizations: How Systematic Errors in Person Perception Undermine Moral Agency. Organization Studies, 27(3),413-428 Mollick, E. (2014). The dynamics of crowdfunding: An exploratory study. Journal of Business Venturing, 29(1), 1-16.

Mollick E. \& Nanda, R. (2015). Wisdom or madness? Comparing crowds with expert evaluation in funding the arts. Management Science. 62(6), 1533-1553.

Montgomery, A. W., Dacin, P. A., \& Dacin, M. T. (2012). Collective social entrepreneurship: Collaboratively shaping social good. Journal of Business Ethics, 111(3), 375-388.

Moss, T. W., Neubaum, D. O., \& Meyskens, M. (2015). The effect of virtuous and entrepreneurial orientations on microfinance lending and repayment: A signaling theory perspective. Entrepreneurship Theory and Practice, 39(1), 27-52.

Nayebpour, M. R. \& Koehn, D. (2003). The Ethics of Quality: Problems and Preconditions. Journal of Business Ethics, 44, 37-48.

Parhankangas, A. \& Renko, M. 2017. Linguistic style and crowdfunding success among social and commercial entrepreneurs. Journal of Business Venturing, 32(2): 215-236. Parhankangas, A., Renko, M.\& McWilliams, A. (2019). He Says, She Says: The Impact of Gender-Specific Linguistic Style on Crowdfunding Outcomes. Academy of Management Proceedings, 1, 12932.

Palazzo, G., Krings, F. \& Hoffrage, U. (2012). Ethical Blindness. Journal of Business Ethics, 109, 323-338. Périlleux A. \& Szafarz, A. (2015), Women Leaders and Social Performance: Evidence from Financial Cooperatives in Senegal. World Development, 74, 437-452.

Pittarello, A., Leib, M., Gordon-Hecker, T., \& Shalvi, S. (2015). Justifications shape ethical blind spots. Psychological Science, 26, 794-804.

Ryan, R. M., \& Connell, J. P. (1989). Perceived locus of causality and internalization: Examining reasons for acting in two do- mains. Journal of Personality and Social Psychology, 57, 749- 761. 
Ryan, R. M., \& Deci, E. L. (2000). Self-determination theory and the facilitation of intrinsic motivation, social development, and well-being. American Psychologist, 55, 68-78.

Scarlata, M., \& Alemany, L. (2010). Deal structuring in philanthropic venture capital investments: Financing instrument, valuation and covenants. Journal of Business Ethics, 95(2), 121-145.

Schicks, J. (2014). Over-indebtedness in microfinance - an empirical analysis of related factors on the borrower level. World Development 54, 301-324.

Schwienbacher, A. 2015. Financing the Business. In (eds) T. Baker and F. Welter, The Routeledge Companion to Entrepreneurship, Routeledge.

Sezer, O., Gino, F. \& Bazerman, M.H. (2015). Ethical blind spots: explaining unintentional unethical behavior, Current Opinion in Psychology, 6,77-81.

Singh, R., \& Mukhopadhyay, K. (2011). Survival analysis in clinical trials: Basics and must know areas. Perspectives in Clinical Research, 2(4), 145-148.

Tchakoute-Tchuigoua, H. (2018). Which types of microfinance institutions decentralize the loan approval process?. The Quarterly Review of Economics and Finance, 67, 237-244

Vismara, S., Benaroio, D., and F. Carne (2017), Gender in entrepreneurial finance: matching investors and entrepreneurs in equity crowdfunding, in A. Links (ed.), Gender and Entrepreneurial Activity, Cheltenham, UK and Northampton, MA, USA: Edward Elgar Publishing, pp. 271-288.

Younkin, P., \& Kashkooli, K. (2016). What Problems Does Crowdfunding Solve? California Management Review, 58(2), 20-43.

Younkin, P., \& Kuppuswamy, V. 2018. The colorblind crowd? Founder race and performance in crowdfunding. Management Science, 64(7): 3269-3287.

World Bank. (2011). World development report 2012: Gender equality and development. World Bank Publications.

Zhang, Q., \& Posso, A. (2017). Microfinance and gender inequality: Cross-country evidence. Applied Economics Letters, 24(20), 1494-1498. 
Business or basic needs?

\section{Tables}

Table 1. Means, standard deviations and correlations

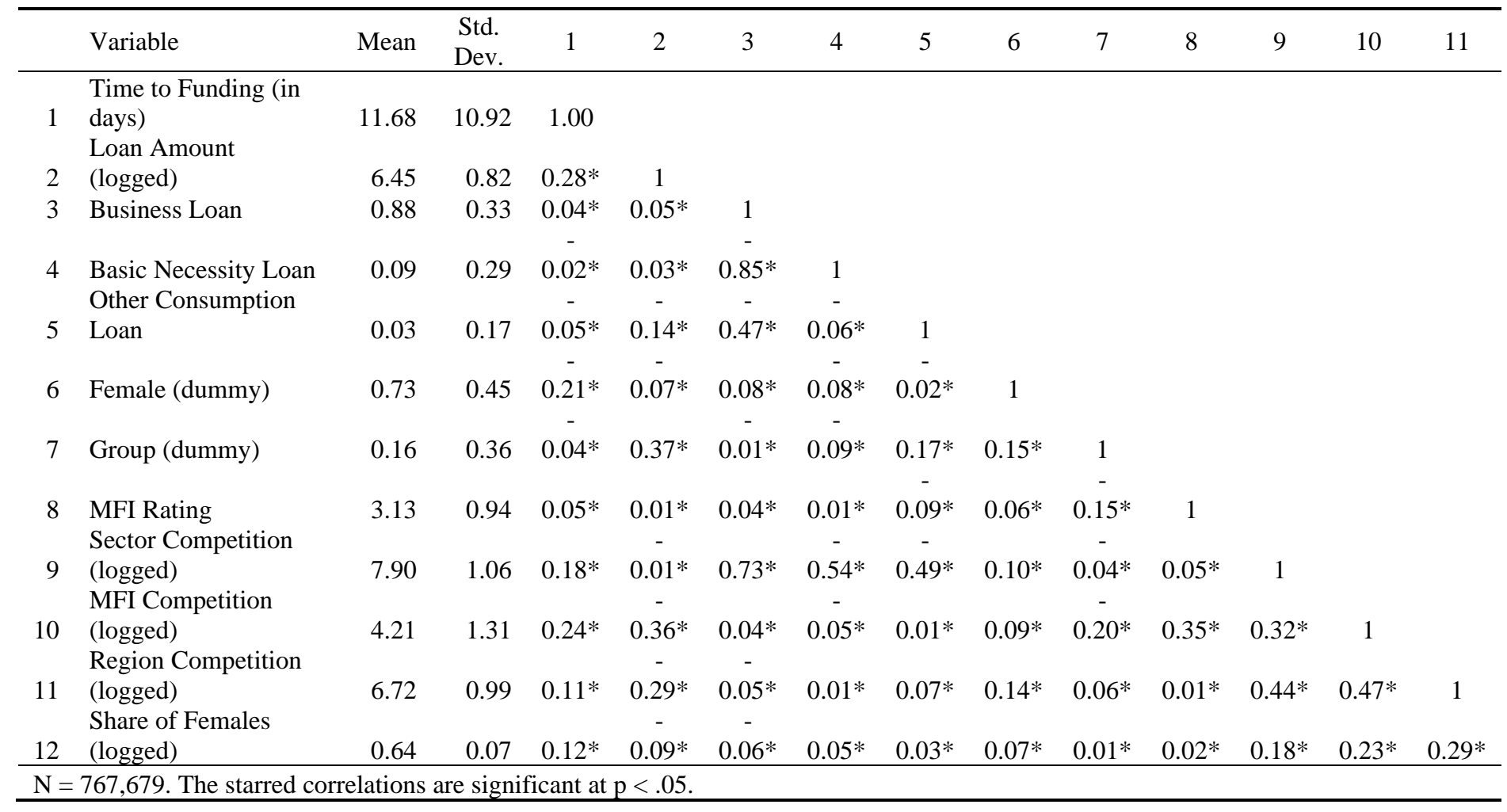

Table 2. Parametric survival model regression results

\begin{tabular}{|c|c|c|c|c|}
\hline & $(1)$ & (2) & (3) & (4) \\
\hline Other Consumption & $\begin{array}{l}0.271 * * * \\
(0.00950)\end{array}$ & $\begin{array}{l}0.361 * * * \\
(0.00990)\end{array}$ & $\begin{array}{l}0.275^{* * *} \\
(0.00956)\end{array}$ & $\begin{array}{l}0.363 * * * \\
(0.00994)\end{array}$ \\
\hline Business & $\begin{array}{c}0.133 * * * \\
(0.0102)\end{array}$ & $\begin{array}{c}1.325 * * * \\
(0.0350)\end{array}$ & $\begin{array}{c}0.0942 * * * \\
(0.0108)\end{array}$ & $\begin{array}{c}1.283 * * * \\
(0.0357)\end{array}$ \\
\hline Female & $\begin{array}{c}-0.483^{* * *} \\
(0.00271)\end{array}$ & $\begin{array}{c}-0.488 * * * \\
(0.00271)\end{array}$ & $\begin{array}{l}-0.538 * * * \\
(0.00715)\end{array}$ & $\begin{array}{c}-0.533 * * * \\
(0.00722)\end{array}$ \\
\hline Log(amount) & $\begin{array}{l}0.811^{* * *} \\
(0.00204)\end{array}$ & $\begin{array}{l}0.971 * * * \\
(0.00493)\end{array}$ & $\begin{array}{l}0.811^{* * *} \\
(0.00204)\end{array}$ & $\begin{array}{l}0.969 * * * \\
(0.00495)\end{array}$ \\
\hline Log(amount)*Business & & $\begin{array}{c}-0.188^{* * *} \\
(0.00530)\end{array}$ & & $\begin{array}{c}-0.186^{* * *} \\
(0.00533)\end{array}$ \\
\hline Female*Business & & & $\begin{array}{c}0.0640 * * * \\
(0.00756)\end{array}$ & $\begin{array}{c}0.0525^{* * *} \\
(0.00763)\end{array}$ \\
\hline Group & $\begin{array}{c}-0.448^{* * *} \\
(0.00387)\end{array}$ & $\begin{array}{c}-0.420^{* * *} \\
(0.00395)\end{array}$ & $\begin{array}{l}-0.447 * * * \\
(0.00388)\end{array}$ & $\begin{array}{c}-0.420^{* * *} \\
(0.00395)\end{array}$ \\
\hline Rating & $\begin{array}{c}-0.0814 * * * \\
(0.00151)\end{array}$ & $\begin{array}{c}-0.0810^{* * *} \\
(0.00150)\end{array}$ & $\begin{array}{c}-0.0815^{* * *} \\
(0.00151)\end{array}$ & $\begin{array}{c}-0.0811^{* * *} \\
(0.00150)\end{array}$ \\
\hline
\end{tabular}


Business or basic needs?

\begin{tabular}{lcccc} 
Log(Type Competition) & $0.0349 * * *$ & $0.0443^{* * *}$ & $0.0342^{* * *}$ & $0.0435^{* * *}$ \\
Log(MFI Competition) & $(0.00408)$ & $(0.00408)$ & $(0.00409)$ & $(0.00409)$ \\
& $0.340^{* * *}$ & $0.339 * * *$ & $0.340^{* * *}$ & $0.339^{* * *}$ \\
Log(Region Competition) & $(0.00130)$ & $(0.00130)$ & $(0.00130)$ & $(0.00130)$ \\
& $0.225^{* * *}$ & $0.217^{* * *}$ & $0.225^{* * *}$ & $0.218^{* * *}$ \\
Share of Female & $(0.00419)$ & $(0.00419)$ & $(0.00420)$ & $(0.00420)$ \\
& $0.909 * * *$ & $0.915^{* * *}$ & $0.905^{* * *}$ & $0.911^{* * *}$ \\
Log(p) & $(0.0184)$ & $(0.0183)$ & $(0.0184)$ & $(0.0183)$ \\
& $0.045^{* * *}$ & $0.043^{* * *}$ & $0.045^{* * *}$ & $0.043^{* * *}$ \\
Constant & $(0.0008)$ & $(0.0008)$ & $(0.0008)$ & $(0.0008)$ \\
& $-6.003^{* * *}$ & $-7.032 * * *$ & $-5.961 * * *$ & $-6.989 * * *$ \\
Region controls & $(0.0328)$ & $(0.0440)$ & $(0.0332)$ & $(0.0446)$ \\
Observations & Yes & Yes & Yes & Yes \\
\hline -2 Log-likelihood & 767,679 & 767,679 & 767,679 & 767,679 \\
Df & $2,302,291$ & $2,300,922$ & $2,302,215$ & $2,300,871$ \\
Akaike Information & 17 & 18 & 18 & 19 \\
Criterion (AIC) & & & & \\
Bayesian Information & $2,302,329$ & $2,300,962$ & $2,302,255$ & $2,300,913$ \\
Criterion (BIC) & & & & \\
Model $\chi 2$ & $2,302,549$ & $2,301,193$ & $2,302,486$ & $2,301,155$ \\
\hline
\end{tabular}

Robust standard errors in parentheses, ${ }^{* * *} p<0.01,{ }^{* *} p<0.05,{ }^{*} p<0.1$

Table 3. Robustness Checks - Matching Method

Panel A - Matching for Business Loan Effect

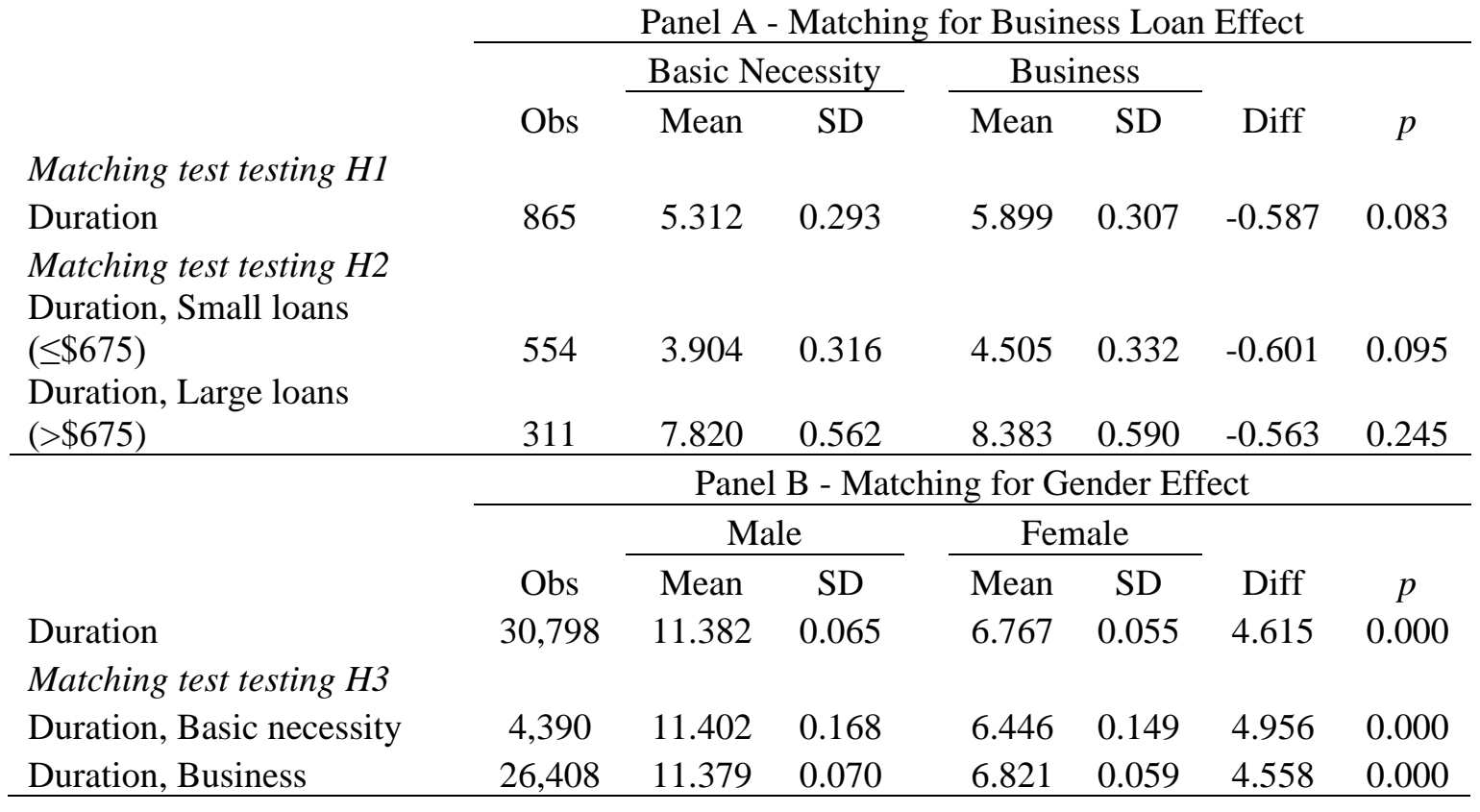


Figure 1. An example of a funded loan request on Kiva

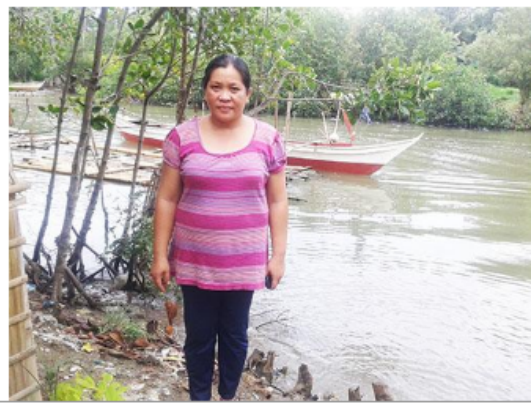

\section{Funded}

Total loan: $\$ 300$

Powered by 10 lenders

Madeline

* $\frac{\text { llog, Negros Occidental, Philippines / }}{\text { Fishing }}$

A loan of $\$ 300$ helped to purchase fishing net.

\section{Madeline's story}

Madeline works hard to support her family. Madeline is married and has a fishing business in the Philippines.

She requested a PHP 13,000 loan through NWTF to purchase fishing net.

Madeline has been in this business for eight years now.

In the future, Madeline would like to save money to expand her business.

This loan is special because:

It helps this borrower grow their business.

\section{Loan details}

(3)

Loan length:

8 months

Repayment schedule: Monthly

Disbursed date: June 15, 2016

Currency exchange loss: Possible

Facilitated by Field Partner:

Negros Women for Tomorrow Foundation

(NWTF)

Is borrower paying interest? Yes

Field Partner risk rating: $\star \star \star \star \star$

Field Partner 